\title{
The roles of migrants and social remittance in traditional festivals' practices in Za Yet Pyin village, Rakhine State, Myanmar
}

\author{
San Yin Yin Tun * \\ Faculty of Social Sciences, Chiang Mai University, Chiang Mai, Thailand
}

\author{
Keywords \\ Migrants \\ Social remittance \\ Traditional festivals \\ Rakhine \\ Actors \\ Networks
}

Received: 15 June 2017

Accepted: 13 July 2017

Published: 21 August 2017

\begin{abstract}
This study focuses on migrants and non-migrants regarding their ideas/suggestions and contributions to the changes in the practices of two traditional festivals, the Water Festival and the Light Festival in Za Yet Pyin village Ramree Island the Rakhine State of Myanmar. The study aims to provide answers by investigating the relationship between actors' roles (migrants/villagers) and the networks founded by migrants. The unit of analysis was distinguished into non-migrants (current residents) and migrants (temporary returnees for Water Festival). The data collection processes such as key informant interviews and participant observation were applied in the research. When recruiting participants, a total of 22 people (10 Females and 12 Males) were accessed. By comparing the pre-migration past and the current migration era, any significant changes in traditional festivals' practices are presented and analyzed, which will bring new findings and insight into the area of migration study in relation to the practice of traditional festivals.
\end{abstract}

(c) 2017 The Author(s). Published by TAF Publishing.

\section{INTRODUCTION}

Migration is the crucial phenomenon which is happening everywhere in the human world. It becomes an interesting issue to be discussed and argued in academic field. Crucially, migration has more meanings rather than it is defined by "people mobilization" because it is related with other issues such as political, socio-economic and cultural of the society.

Myanmar, one of the Southeast Asian countries is the largest migration source country in the Greater Mekong sub-region, and was estimated to have 10\% of Myanmar population moving out of the country (International Organization for Migration, 2015). The international community still recognizes Myanmar as the least developed country owning the status of prosperity as-lower middle income level.

In Myanmar, majority of Burmese and other official ethnic groups such as Kachin Kayah, Kayin, Chin, Mon, Rakhine and Shan are living with other minority groups of people. Ethnic Rakhine is one the major ethnic groups of Myanmar; their region "Rakhine state' is situated at the eastern side of Bay of Bengal, and share international border with Bangladesh, internal boundaries with Chin State, as well as Magway, Bago and Ayeyarwaddy regions. Rakhine was spotlighted in international news about Rohingya issue. However, this introduction will say about poor socio-economic condition and massive flow of migration of Rakhine state.

\footnotetext{
${ }^{*}$ Corresponding author: San Yin Yin Tun

†Email: sanyinyin.tun@gmail.com
} 
Today, the status of Rakhine is noted as one of the poorest regions in Myanmar. Regarding World Bank Group's report (2014), Rakhine State is marked with its poverty rate of 78 percent compared to $37.5 \%$ percent nationally. Lack of infrastructure is the root cause to happen the region to be a poor ethnic region. Local people from the region are experiencing difficulties in their daily life, and struggle to have some income covering basic needs. According to World Bank Group's report (2014) below 10 percent of electricity was accessed by Rakhine region. How rigid situation is that local Rakhine people cannot access electricity fully, though they are living in the place enriching natural gas.

In accordance with the World Bank Group (2016) report "Livelihoods and social change in Rural Myanmar" improvements in agricultural-based livelihoods was accelerated significantly in Shan, Chin and Ayeyarwaddy regions, but lesser growth in Magway and Rakhine regions were remarked. According this report, it can be analyzed that Rakhine people relying on their traditional economies such as agriculture and aquaculture could not have higher incomes for strengthening their socio-economic situation. In the region, it has the lowest percentage of households with access to improved sanitation in the country (48\% compared to a national average of $84 \%$ ), as well as the lowest primary school enrollment rate $(71.4 \%$ compared to a national average of $87.7 \%$ ) (International Organization for Migration, 2015). Therefore, it can be thought that development situation of Rakhine people are low level in accordance with their socio-economic status and life skills.

To overcome economic stress or to access higher education, moving out of their place becomes one of their coping mechanisms. Pushed by limited livelihoods, and poor socioeconomic conditions, local people from Rakhine highly migrated out of the region. Specifically, $80 \%$ of young people from that region moved out of Mrauk-U Township for their financial security and so on (International Organization for Migration, 2016a). Almost three-quarters of young men in some townships of Rakhine State moved out to find works, especially internal regions; Kachin State or Yangon and foreign countries such as Thailand or Malaysia (Su, 2016). When analyzing people's mobility from the region, there is both rural- urban migration and transnational migration. The huge problem in transnational migration is that irregular migration was figured out in Rakhine state although people from other regions went out of the country with documented status. International Organization for Migration (2016b) report "Labour Mobility" mentioned that most of them migrated to neighboring countries such as Thailand, Malaysia, and China as "undocumented labours" and some were victims of human trafficking. 10\% out of thousands of Myanmar nationals trafficked to fishing boats in Indonesia were ethnic Rakhine (International Organization for Migration, 2015).

It can be regarded that almost every part of Rakhine has been experiencing migration. In academic field, previous studies such as migration effect on socio-cultural economy of the migrant sending community (May, 2015, ; Potjaporn Joonlaoun, 2017) and social capital and Rakhine migrant workers in host community (Aung, 2015) revealed significant outflow and internal young migration from Rakhine state. Although there are a few studies related to migration in Rakhine, a gap of knowledge about migration effect in sending community is needed to be contributed to the migration field of study. Therefore, this study was purposed for getting to know how migration affects on traditional practices in home community. In accordance with the aim of this study, Za Yet Pyin village situated in Ramree Island, Rakhine state was chosen because it has been experiencing massive flow of young and young adults' migration for over two decades. Therefore, it could be realized that this study has relevance with the previous studies based on a strong concern for young mobility from Rakhine State. Among a lot of traditional practices of Za Yet Pyin vil- 
lage, the traditional festivals such as Water and Light festivals were intentionally selected. This becomes what is studied in this paper.

In local Rakhine version, it is important to note that Water festival is known as Thungran festival. Plus, Light festival is called as War Kywat-See mee lights festival in local Rakhine people. The ethnic Rakhine celebrate Thungran festival in the month of April. Rakhine people have the perception that they feel dirtiness can be washed from old year by sprinkling water over each other during the period of Thungran festival days (Maung, 2004). The purpose of celebrating War Kywat-See mee lights festival is related with Buddhists' traditional perception. Almost all people of Za Yet Pyin village devotion in Buddhism have same perception with Burmese Buddhists in relation with the reason of offering lights. This practice of offering lights was emerged from welcoming Lord Gautama Buddha preaching his mother in Abode of celestial beings for three Lenten months and returning to the abode of male on the full-moon day of Thadingyut (which is known as the month of October in Christian calendar). The King of Celestials created gold, silver, and ruby stairways for him.

Buddha took the middle ruby one radiating six hues of aura. The nats came along by the right gold stairways and the Brahmas by the left silvery stairways. On account of that, Myanmar Buddhists celebrate the full-moon day with multi-colored illuminations. However, Za Yet Pyin village could organize this festival in the month of November because of heavy rain in October.

The main interest of the study is how migration impacts; role of actors (migrants and non-migrants) and their remittances effect on traditional festivals of Za Yet Pyin village. It could be revealed by proposing the following questions: how role of actors, especially collaboration of migrants and non-migrants and remittances transmitted through networks affects Thungran festival (Water festival)? How only support by non-migrants affects on War-Kywat See mee lights festival (Light festival)?

METHODOLOGY

This research conducts qualitative approach and case studies of Thungran Festival (Rakhine Water festival) and War Kywat-See mee lights Festival (Rakhine Light festival). According to Creswell (2007), the qualitative method is much useful when studying the interaction among people of the community and getting to know the real situation of the community in depth.

\section{Research Site and Researcher Role}

In the nature of qualitative method, I, the researcher conducted data collection from the research site. The research is conducted through two times of visits to Za Yet Pyin village, Lay Taung Region which is located on Rameree Island in Rakhine State. As this research study is on seasonal festivals, it was concerning the fact that I should have to get there in the particular period in which the traditional festivals are going to be held. Therefore, I was there to observe these traditional festivals in April and November.

There are two main researchers' roles in doing researches - emic and etic, that explains how and from which perspectives the researchers will be conducting research while collecting data and doing interviews and observations throughout the research processes (Creswell, 2007). Throughout this research, the researcher took both of the roles - emic and etic because I am Rakhine and understand their culture and dialect. On the other side, I was not a member of the community that means I was not born and grown up there.

Unit and level of analysis: For this research, my purposive samples are the community people who are now living in the village as well as temporary returnees coming back for a short visit and some responsible of migrants' networks. So, the unit of analysis was distin- 
guished into non-migrants (current residents) and migrants (temporary returnees for Water Festival). When recruiting participants, I had a total of 22 people (10 Females and 12 Males). For my gatekeeper, one of the village leaders was approached. The person helped me for the research, especially facilitating opportunities to get entry into the population and engaging to meet the informants. He was helpful when selecting the participants, approaching the informants and asking the information of the local context throughout the research.

In the level of analysis of this research, individual and community levels are mainly divided. At the individual level, participants; categories of migrant and non-migrants were conducted for understanding of their social memories and experience as well as their particular roles for the festivals. At the community level, the researcher did observation on the communal activities; these two festivals during the particular moment.

Data collection: In the research, the data collection processes such as key informant interviews, and participant observation were applied. For the main priority, participant observation had been focused. According to Punch (2014), participant observation is the central data collection technique in ethnography which is helpful to study the assembly of people, their behaviors and relations (Punch, 2014). Therefore, observations on the two festivals in April and November were seriously applied. After trying to get experience from observation first, in-depth interviews with key-informants were conducted. According to Punch (2014), it is a very good way of accessing people's perceptions, meanings and definitions.

\section{FINDINGS}

According to different nature of the two festivals, findings are presented by separating the category of Thungran festival (Water Festival) and War Kywat-See mee lights festival (Lights Festival).

\section{In Thungran Festival (Water Festival)} Changes in traditional festivals' practices by cooperation of migrants and non-migran$t s$ : In this part, how to support by the role of actors especially migrants , non-migrants and remittances brought by migrants is presented for this thesis intention which is to make analysis relations of the role of actors, and how to affect on the village's Thungran festival. Then, what significant changes in Thungran festival's traditional practices are explained by course of migration effect in the current migration era.

1. Role of migrants and non-migrants in Thungran festival: In the village's Thungran festival held in April of 2016, people from Yangon returned to the village for enjoying this cultural practice. When coming to the village, they joined to the particular social group, such as single group (a group which is composed of single people) and married group (which is composed of married people) according to their current marital status and carried out responsibilities of community works together. According to this situation, Mr. Pyae Phyo, the leader of Youth Literacy and Volunteering Network shared with me like this:

Although we are away from the village, our membership status is still alive. Our family members gave the annual membership fees to the village committee. When we returned to the village, we just joined the particular groups. If we got married already, we would work with married group members. I'm still single. When I returned to the village for Thungran festival, I was a member of single group again and, worked together with my other friends, and juniors. I mean juniors are current young members of single group. We knew Thungran festival could happen even if we, returnees are involved in organizing activities. I can say only village community could not organize the whole festival because it has a lot of activities (Field note, November 2016). 
Instead of carrying out communal works separately by themselves, they did reintegrate to the village community by cooperation with non-migrants. By collaboration between migrants and non-migrants, they could manage all kinds of activities included in the festival and support the continuity of the village's Thungran festival.

Moreover, the role of migrants was recognized as the key player for managing the whole procedure of the festival because they supported the festival by sharing financial costs, and ideas or suggestions. When supporting the village's festival by migrants, it should be seen as migrants network's contribution rather than individuals of migrants. There are three networks namely; Social Service Network; Youth Literacy and Volunteering Network; Youth Network composed of local Rakhine people from Za Yet Pyin village, and they are hosted in Yangon. The leaders of these networks connected with some focal people from the village, and discussed how to plan the festival. Since the earlier time before starting the festival, there had been pre-discussions, and planning of how to organize, and arrange the activities of the festival. In accordance with how to support financially from these three networks for this festival, Mr. Pyae Phyo explained to me like this:

We made discussions when gathering our group members. Our leaders of each group met and discussed about it how we should support and help for organizing the village's festival. You know, our networks' funds gave the costs for making all uniforms for young women for contesting of playing water, and moreover, we contributed any cost for arranging the ceremony of paying homage to elders, and then arranged buying the gifts for elders by using our networks' funds. And then, we shared some costs for arranging the whole process of Thungran festival of the village (Field note, November 2016).

Furthermore, migrants' networks shared their ideas /suggestions along with financial assistance to non-migrants when arranging the activities of the festival. Mr. Kyaw Kyaw, a leader of Social Service Network shared with me how they shared his ideas/suggestions among some adults from the village: Before leaving Yangon, we proposed our ideas/suggestion to village leaders, and some adults in advance. We let them know our plan about bringing new uniform dresses made of cotton, and asked them for their opinion. We asked them to start collecting some natural products for building tent without waiting for our coming in the village. We seriously discussed with them about the special regulation for not allowing alcohol beverages, and other regulations.

We discussed other permissions, and other regulations with the village leaders... Then, I just shared some new updates with the networks' members in Yangon, and requested them to behave responsively and obediently with the elders, and friendly with the younger generation (Field note, April 2016).

In accordance with this information, they had been planning well by connecting with non-migrants before leaving Yangon. Therefore, it can be regarded that importance of the role of migrants was obvious for organizing the festival with the support of financial input, and sharing ideas or suggestions. Reintegration of migrants, non-migrants and supporting by migrants/non-migrants networks was very helpful for organizing the festival successfully. Importantly, some changes in local traditional practices were related to the effort, and involvement of role of actors.

2. Changes in traditional practices of Thungran festival: In the village's Thungran festival, core essences such as dual contesting between two sexes of playing water and placing loung (which is a wooden rowboat) as a water container in contesting of playing water were still practiced. The ways of procedures of the village's festival could be different from other parts of Rakhine region because it can be said that some activities of the festival are localized based on the village's geographical location. Through observation, and interview 
from the village's Thungran festival in April of 2016, some of the traditional practices were starting to be changed by course of migration impact; roles of temporary returnees and remittances. Among changes in local traditional practices, some were new things added without removing old norms and practices. However, a few local practices were totally weakened when they were not counted as the essential things in the current condition. From the research during the period of Thungran festival days, the following significant changes in local traditional practices were shared.

a) Declination of the local practice of carrying loung from sea side into the village: In dual contesting of playing water, placing a loung as a water container could be seen as core essence of Rakhine Thungran festival. This village still preserves this symbol whenever organizing the village's Thungran festival. There was another local custom which was practiced by this local community since the past time till 2014. It was a traditional practice -carrying loung (which is a wooden rowboat) from sea side into the village by manpower. This traditional local practice was included in the preparation process as an important activity before starting dual contesting of playing water. Significantly, this local traditional practice could not be seen in other different parts of Rakhine, and it was only practiced by this village community. According to this local traditional practice, Mr. Pyae Phyo, 28 years shared his past experience when participating in this kind of community work in 2014;

When returning to village in 2014, I involved in this group of carrying boat. I was really excited. Manpower is really needed to carry it from sea side into the village. Without harmony, we can not carry it into the village because it is so heavy. We negotiated with the fisherman with some cash and borrowed it from him. When carrying it into the village, the villagers welcomed us and applauded by shouting and laughing a lot... (Field note, October 2016).

In this sense, this traditional local practice showed solidarity and cohesiveness of this community. The practice of carrying loung (wooden rowboat) from sea side into the village can be recognized as local cultural identity as well as social harmony of community people, especially young men from the village.

However, this lovely local traditional practice was starting to be declined, and it could not be sustained in the village's festival in 2016. Instead of carrying used wooden rowboat from sea-side into the village, the new wooden boat was bought and installed as the water container in the contesting ground. This was one of the significant changes of traditional practices in the migration era. The role of migrants was a key player for organizing the activities of the village's Thungran festival. Although they tried to sustain some local practices, they could not engage people participating in this community work- carrying loung from sea side into the village when they reconsidered time cost and availability of people for this practice. As an alternative way which can sustain the core essence of Rakhine Thungran festival, they suggested their idea - buying of a new wooden rowboat. Concerning with this, the chairman of Za Yet Pyin Social Service Network explained to me like this:

We gave suggestion and asked the village community to buy new boat and set up there. We thought it is much better. We don't need to ask volunteers to carry it. It is a matter that there is a boat when playing water. (Field note, October 2016).

Community people gave more priority to the core essence of placing boat in the temporary tent. On the other side, they did not think of the importance of local practice- carrying loung from sea side into the village's temporary tent by manpower. By adopting the new way, they did not need to think for the arrangement of carrying loung from sea side into the village for future and asking volunteers for this communal work. Today, this traditional local practice could not be seen again in this village. This practice was declined absolutely 
after adopting the new way for resolving their difficulties. As a key player for arranging the activities of the festival, temporary returnees could be said as the original developer who initiated this idea, and engaged the villagers to adopt this new thing for considering time and availability of people.

b) Declination of the local of practice of making traditional Thungran food: Mhote Phat Htoke: In the past, there was an old traditional local practice-making Mhote Phat Htoke during a period of Thungran festival days. Home-cooked Mhote Phat Htoke is a simple dessert which is wrapped by coconut-leaf and inside the small pyramid shape package is a small amount of jam made up of palm-sugar and coconut meat. Before starting the welcome day of Thungran festival, the village girls of single group were assigned for making Mhote Phat Htoke for purposing contribution of food to people attending and encouraging dual contesting of playing water. This was their local traditional practice-contribution of Mhote Phat Htoke to people who came to watch and participate in this contesting of playing water and it was particularly practiced during a period of Thungran days. However, this traditional local practice could not be sustained in the migration era. Instead of contribution of Mhote Phat Htoke, other ready-made liquids were replaced for refreshment. In accordance with the declination of making Mhote Phat Htoke, an elder woman Mrs. Mya Mya, 65 years criticized like this:

I heard that they were not interested in it anymore. Girls are more interested in how to show up beautifully in the festival instead of making home-cooked dessert. I don't want to interfere in every affair when I am now very old (Field note, October 2016).

Additionally, Mrs. Cho Cho, 32 years expressed her thought on the declination of homecooked Thungran food like this:

I knew this kind of dessert could not be made in April. Returnees cannot organize at all. The current members from the single group are different, not like us. They are more interested in their study and other enjoyable activities. Although they have some of free time in Thungran period, they wanted to spend watching movie, or using internet through their phones (Field note, October 2016).

In accordance with the opinion from these two women from the married group, it is thought that value of this traditional practice was changed when young generation was not passionate about it. Also, some young adults especially the returnees even did not think that it is not a kind of important procedure. When adopting the easiest way of contribution of liquids, not only old local practice but also the sense of "togetherness" for achieving the communal work were challenged in the current migration era.

c) New practice of uniform dressing by young girls when playing water: During the middle days of the village's Thungran festival, the activity of dual contesting of playing water between two sexes was organized near the village's library. This was another significant finding which was figured out in the activity of dual contesting of playing water. It was that the village girls and young women from Za Yet Pyin village played water by wearing uniform dressing which is made of cotton. In my observation, they were very unique among other young women from other villages.

This practice-wearing uniform dresses in dual contesting of playing water was not originally from the village, and it was brought by migrants returning to the village for this festival. The chairman of migrant network who advocated the young members of the village to follow the new practice explained to me about this:

We heard elders' complain about the young's fashion. I understood elders can not follow modernized designs with time. We group discussed about it seriously before coming to the village. We had an idea to request these teenagers to wear neat and tidy, to wear 
traditionally. Also, our village acted as a host for competition of playing water; we wanted to show something different among other villages. I had an idea about how to borrow this practice of wearing uniform. I noticed Burmese group traditional dance by wearing uniform in Water Festival in Yangon. We all liked this idea.... Some migrant women supported our idea/planning by making uniform dressing for young females in the village. When gathering migrants in Yangon before entering the village, we encouraged young women to wear uniform dressing. We will also carry some dressing for village girls (teenagers). No matter what trend the girls follow, but we also wanted them to follow this regulation during this short time (Field note, October 2016).

This practice was purposed for showing decent and gentle characters of Za Yet Pyin village's girls. Also, it was intended for showing distinct and uniform nature of Za Yet Pyin village's Thungran festival. This practice was developed with the idea and suggestions from the returnees, especially some leaders from migrant networks.

However, another different opinion which is against this new practice was found out from group discussion with young girls. They had a feeling of disatisfaction about dressing in cotton uniforms although they showed themselves in uniform dress in the contesting activity. In fact, they had inconvenient conditions when they got wet because of playing water. One of the girls from group discussion with current single group member stressed the strength of jean pants and weakness of cotton uniform dressing like this; I feel more confident and comfortable when I get splashing water. I don't really like this uniform because its skin is very thin and not suitable for competition of playing water.

tab Therefore, the two different opinions on this new practice were figured out. The ethnic community giving priority to seniority, influence of senior or elder people was noted from these differences. However, this kind of new practice by course of temporary returnees showed uniqueness and creation of Za Yet Pyin village among other neighboring villages. Also, it can be seen as the newly developed practice without affecting the old cultural practices negatively.

d) New practice of using vehicle for going to neighboring village's pandals: According to the festival's procedures, young people from single group went around the other villages for participating in the competition of playing water in the past. They walked around other neighboring villages with the musical group, and enjoyed in other villages' Thungran festival.

However, this kind of attending together by walking for getting splashing water was declined when they chose the vehicle instead of walking. In the festival of 2016, this scene was figured out in a group of people taking a light truck and going around the other villages' pandals to enjoy the completion of playing water. And, this kind of new practicevisiting around the pandals by vehicle could be found out easily in the festival of urban regions. In accordance with adoption of urban practice in this village's festival, Mr. Pyae Phyo explained to me like this: We did visit to the other villages' pandals by walking with musical group under the sun.

Destination is too far between one village and another. Sometimes, we were very tired and sick next day after walking for many hours under the sunlight in the summer. We just considered for females because they were not sure to be comfortable with walking after staying in the cities for so long. These children (teenagers/younger generation of single group) preferred to go there by truck instead of walking there. We just discussed in our network to do like that we did visit to the pandal by car in Yangon in Thungran period. We just adopted this pattern and asked the village's married group members to hire a big truck. We supported it from our network and a few from the villagers (Field note, October 
2016).

According to the information, local people adopted this kind of urban practice through time by consideration of cost of time and energy. Also, this kind of new practice was brought by temporary returnees' and applied in the village. In current migration era, the traditional local practice was declined when adopting new practice introduced by temporary returnees.

In War Kywat-See Mee lights Festival (Light Festival) Diffusion of traditional village management system in war Kywat-See mee lights festival

1. Role of non-migrants in war kywat-see mee lights festival: In Za Yet Pyin village's War Kywat-See mee lights festival, people from Yangon could not return to the village. Without the involvement of migrants, the whole procedure of the festival was arranged by non-migrants from the village. In fact, this festival took about two days, so there are not many activities included.

In real, the village has been experiencing loss of human resources; especially young active leaders by course of rural dislocation. When this festival was recognized as the important ritual practice by Buddhist society, the village community tried to involve for the continuity of this ritual practice. Throughout the festival, role of adult members was more apparent than role of young members when they have the critical situation - less of young people. When migrants did not return to the village during the period of the months of October and November, War Kywat-see mee lights festival's most activities were arranged with adult members of married group people.

2. Diffusion of responsibility between single and married groups: War Kywat-See mee lights festival took about two days without preparation day for general cleaning. On the first full moon night of the festival's days, community people from all villages assembled together in the religions space which is in the middle of Lay Taung Region. In that religious space, all people including elder and young people offered candle lights, and prayed there together. After that, Za Yet Pyin villagers organized this kind of ritual practice on the second night. At the ritual performance organized by Za Yet Pyin village, they arranged to make worship, and offer candle lights at their village's monastery compound.

Before starting Za Yet Pyin village's War Kywat-see mee lights festival, the village communal work include general cleaning around the monastery's compound as well as the village's streets.

This communal work could be said as the very important preparation process. Since the past time, this communal work- general cleaning had been carried out by single group members. Therefore, it could be regarded as traditional communal work during the period of War Kywat-see mee lights festival.

According to the village's traditional social system, there were division of responsibilities in communal works accounting for social groups such as single group and married group. In the past, single group members took much responsibilities as volunteers in the village's social affairs. However, the functions of single group were weakened obviously after a massive flow of young people in migration. This kind of situation could be found out in general cleaning process in preparation period. According to the village's tradition, this communal work- general cleaning was traditionally assigned to the particular single group particularly in the past. Differently, it was found out that general cleaning was volunteered by married group people on the behalf of single group member in 2016 . The reason why adult members of married group carried out the communal work on the behalf of young members was figured out from this interview with Mr. Khin Hla, a member 
of Married group:

Sometime, the community works interrupt their concentration on study, I believe. We want to see our children as educated people, to get higher education. I don't want them satisfying their lives by living in the island. Thus, I came to volunteer for general cleaning instead of my daughter. My child was not feeling happy because she was worried that she could be misunderstood by others when staying away from the community work. I reminded her to focus only on her study. But, I allowed her to go to offer the lights on the main day of the festival. She went to offer some lights to the temple with her friends on the full moon night. (Field note, November, 2016).

In contrast to his opinion, Mr. Khin Maung, current married group member who had been a leader of single group shared his feeling on this kind of situation like this:

I feel that young are not matured enough. The community, even their parents, and elders treat them as children. They don't think of themselves like matured young people. When we were young, we acted differently. We went to school regularly, and tried to create personal time for chatting with our peers, gathering at the village's library with other single group members and involving in some of the community works. We did know well how to manage time. Thus, we were strong when studying in Yangon because we understood how to manage to ourself with self-regulation (Field note, October 2016).

By comparison between two different views, it was thought that there are arguments on diffusion of social structure and social groups in their responsibilities of community works. There can be particular people like Mrs. Khin Hla who concern that their children can lose their concentration on their studies when they take part in community works. Therefore, they involved themselves in this kind of communal work by taking the responsibility of single group members. Differently, some people like Mr. Khin Maung thought by recalling their experience that young should be active in their studies as well as other community activities if they are recognized as members of the community. And, they wanted to claim that it is kind of a way to practice themselves how to enhance their social skills, and their maturity.

Whatever, change in clear division of social structure of the village's traditional management system was figured out. Also, it can be analyzed that it was resulted when there were no enough young members in single group in that period. In other words, it is more apparent that less young members, especially young leaders as a consequence of outflow migration is challenging to the social structure of the village system. This negative effect could be found out when there was no involvement of migrants in War Kywat-see mee lights festival.

\section{DISCUSSION AND CONCLUSION}

As this study focus on the two traditional festivals, analytical discussion is presented by referring some findings from these two festivals, linking with the literature review.

In Thungran festival (Water festival), cooperation of migrants and non-migrants could manage all important activities of the festival, and maintain core essence of Rakhine Thungran festival, by arranging dual contesting between two sexes, and placing loung (wooden rowboat) as a water container. The significant thing is that some practices were declined by adopting new ways after leaving the old ways. It could be figured out in these two things such as "declination of the local practice of carrying loung from sea side into the village" and "declination of the local practice of making traditional Thungran food: Mote Phat Htoke". Another things is that some practices were introduced in this village commu nity by bringing urban practices and applying them in the local context. It could be found out in these two things such as "new practice of uniform dressing by young girls, and new 
practice of vehicle for going to neighboring villages' pandals.

When analyzing these changes, role of migrant, and non-migrant networks is the main player for the happening of these kinds. According to the role of organizer, they just shared financial costs for arranging activities. It could be thought that this festival relied on financial support from migrants (individuals) and networks (collective). Therefore, some amount of financial contribution is the economic remittance from migrants sending back money or goods to their home commu nity (Adams, 2009). These migrants could be seen as a tool for generating these activities of the festival. Moreover, migrants supported not only financial elements butalso their ideas or suggestions for arranging the festival. Through the leaders of migrants' networks, they just sent social remittances (individual, collective) which is defined as the transmission of ideas and behaviors (normative structures) and making actions (practice) through social capitals between host and destination (Levitt, 1998). According to definition on social capital by Levitt (1998), it can be recognized as who control the quality of social remittances.

In analysis of what changes, and how changes in traditional local practices in relation to the migration, and its consequences, it could be argued that quality of social remittances (individual, collective) can make change, or maintain traditional practices. According to Levitt and Lamba-Nieves (2010), social remittances have both qualities such as modification and reintegration between receiving and sending communities. Thus, it would be argued that the village's Thungran festival was continued with the role of economic, and social remittances from migrants/network. More importantly, some core essences, and values could be maintained by course of quality of social remittances. Also, due to the quality of social remittances, some practices become changed by adopting new things, and giving up the old things. From Thungran festival of Za Yet Pyin village, this argument is issued that role of social remittances is not tangible. However its effects are severe and huge.

In War Kywat-See mee lights festival of the village, role of non-migrants became the main key player for arranging the whole procedure of the ritual practice when it is noted that migrants returned to the village during that period. More importantly, the village community coping with the real situation after massive flow of migration could be figured out in this festival. In War Kywat- See mee lights festival, there was diffusion of responsibilities between single group and married group when carrying out general cleaning during preparation period. It happened when married group members volunteered this work on the behalf of single group members although this work was traditionally taken by single group members. As there are less number of young active leaders, the village community encounters not enough active and energetic people whenever organizing the communal activities. It could be seen as a negative effect of migration on the sending community. According to King and Vullnetari (2006), this argument was addressed that young/young adults' migration can disrupt social and kinship system of the community. From War Kywat- See mee lights festival of Za Yet Pyin village, this argument is launched that diffusion of social structure was due to fewer young members in the single group. In other view, it is one of the threats challenging to the traditional village management system.

In an academic field, migration is acknowledged as an important issue as clearly shown by a large number of migration studies (see for example, Aung, 2015; Cung, 2015; Fan and Stark, 2008; Hare, 1999; Junge et al., 2015; Malik, 2015; May, 2015; Nguyen et al., 2015; Wouterse and Taylor, 2008). 


\section{LIMITATIONS AND RECOMMENDATIONS}

There are not many studies presenting relation between traditional practices and migration. In academic field, it is very rare to study this kind of dimension. The study is although one of the few studies, investigating this domain, yet a lot more needs to be investigated. Hence, future research is advised to cater fro the limitations of this study and replicate this study for better results.

\section{REFERENCES}

Adams, Richard H. 2009. The determinants of international remittances in developing countries. World Development 37, no. 1: 93-103. DOI: 10.1016/j.worlddev.2007.11.007

Aung, Mуо М. 2015. Rakhine migrant factory workers' social network, knowledge and learning process in Hlaign

Thar- yar industrial zone in Yangon, Myanmar. Ph.D. dissertation, Chiang Mai University, Chiang Mai, TH.

Creswell, John W. 2007. Qualitative inquiry \& research design: Choosing among five approaches. California, CA: Sage Publications Ltd.

Cung, Lian H. 2015. Community networking and remittances as social capital for rural community development, Chin state, Myanmar. Ph.D. dissertation, Chiang Mai University, Chiang Mai, TH.

Fan, C. Simon, and Oded Stark. 2008. Rural-to-urban migration, human capital, and agglomeration. Journal of Economic Behavior \& Organization 68, no. 1: 234-247. DOI: 10.1016/j.jebo.2008.04.003

Hare, Denise. 1999. Push' versus 'pull' factors in migration outflows and returns: Determinants of migration status and spell duration among China's rural population. The Journal of Development Studies 35, no. 3: 45-72.

DOI: https: 10.1080/00220389908422573

International Organization for Migration. 2015. 10 years of IOM in Myanmar (2005-2014). URL: https: goo.gl/SPRd3b (accessed May 29, 2017).

International Organization for Migration . 2016a. IOM appeal (Myanmar/Rakhine state). URL: https: goo.gl/44RRyk (accessed May 26, 2017).

International Organization for Migration. 2016b. Labour mobility. URL: https: goo.gl/7SVrcb (accessed June 1, 2017).

Junge, Vera, Javier Revilla Diez, and Ludwig Schätzl. 2015. Determinants and consequences of internal return migration in Thailand and Vietnam. World Development 71, no. 2: 94-106. DOI: 10.1016/j.worlddev.2013.11.007

Potjaporn, Joonlaoun. 2017. Remitting behaviors and intention to return home of Thai migrant workers in Australia: A study of income, employment and legal satisfaction. Journal of Advances in Humanities and Social Sciences 3, no. 1: 29-41.

DOI: https: $10.20474 /$ jahss-3.1.3

King, Russell, and Julie Vullnetari. 2006. Orphan pensioners and migrating grandparents: The impact of mass migration on older people in rural Albania. Ageing \& Society 26, no. 5: 783-816. DOI: https: 10.1017/S0144686X06005125

Levitt, Peggy. 1998. Social remittances: Migration driven local-level forms of cultural diffusion. International Migration Review 27, no. 8: 926-948. DOI: https: 10.2307/2547666

Levitt, Peggy, and Deepak Lamba-Nieves. 2010. It's not just about the economy, stupid social remittances revisited.

URL: https: goo.gl/1K5ynd (accessed June 1, 2017).

Malik, Asma S. 2015. Rural urban migration: Socio-cultural changes in Pakistan-preventive measures taken by govern- ment and civil society to control it. Professional Medical Journal 22, no. 6: 22-26.

Maung, Tha H. 2004. The rakhaing. New York, NY: Buddhist Rakhaing Cultural Association.

Nguyen, Loc Duc, Katharina Raabe, and Ulrike Grote. 2015. Rural-urban migration, household vulnerability, and welfare in

Vietnam. World Development 71, no. 9: 79-93. D0I: https: 10.1016/j.worlddev.2013.11.002

Punch, Keith F. 2014. Collecting qualitative data in introduction to social research qualitative and quantitative approa-'newline

London, UK: SAGE Publications Ltd.

May, Saw Yu. 2015. Migration as a shallenge for Myanmar's socio-economic development: Case studies of Hpa-An and

Mrauk-U townships in Myanmar. Paper presented at the International Conference on Burma/Myanmar Studies, Chi-

ang Mai University, Chiang Mai, TH. 
Su, Phyo W. 2016. Migration drains residents of hope. URL: https: goo.gl/d3jivu (accessed May 26, 2016). World Bank Group. 2014. Myanmar ending poverty and boosting shared prosperity in a time of transition.

URL: https: goo.gl/8nukwi (accessed May 29, 2016).

World Bank Group. 2016. Livelihoods \& social change in Myanmar. URL: https: goo.gl/QFMrrm (accessed May 26, 2016). Wouterse, Fleur, and J. Edward Taylor. 2008. Migration and income diversification: Evidence from Burkina Faso. World De- velopment 36, no. 4: 625-640. DOI: https: 10.1016/j.worlddev.2007.03.009

— This article does not have any appendix. - 